
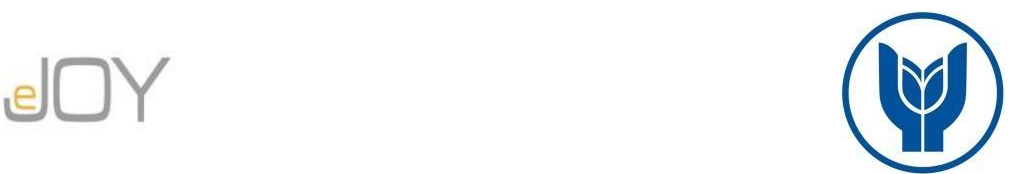

Özden, M., Kantar, G., Çınar, S. / Journal of Yasar University, 2021, 16/62, 1005-1021

\title{
Kentsel Markalaşma Sürecinde Yerel Yönetimlerin Önemi
}

\section{The Importance of Local Governments in the Urban Branding Process}

\author{
Miray ÖZDEN, Tekirdağ Namık Kemal Üniversitesi, Türkiye, mirayozden0@gmail.com \\ Orcid No: 0000-0001-7998-9699 \\ Gökmen KANTAR, Tekirdağ Namık Kemal Üniversitesi, Türkiye, gkantar@nku.edu.tr \\ Orcid No: 0000-0001-5120-110X
}

Sabri ÇINAR, Tekirdağ Süleymanpaşa Belediyesi, Türkiye, sabricinar@suleymanpasa.bel.tr Orcid No: 0000-0002-6924-5589

\begin{abstract}
Öz: Hızlı nüfus artışı ile birlikte kentleşmenin artması, kentlerin artık hem ticari hem de siyasi anlamda cazibe merkezlerine dönüşmesine yol açmıştır. Kentlerin üstlendikleri bu önemli rol, yerel yönetimlerin de kentsel politikalar konusunda yeni stratejiler belirlemesine neden olmuştur. Bu sebeple, kentlerin cazibe merkezi olarak değerlendirilmesinde markalaşma çalışmalarının arttırlması ve yerel ekonomik değerlerin yeniden belirlenebilmesi amacıyla belediyeler, stratejik kent yönetimi konusunda da yeni görev alanlarının oluşturulması çalışmalarına ağırllk vermişlerdir. Kentsel markalaşma, sürdürülebilir şehirlerin kentsel geliş̧imine yönelik yeni bir yaklaşımdır. Kentsel iletişimin yeni bir yönü olan şehir markalaşması, şehrin görsel imajını marka imajına dönüşürerek şehir imajının pazarlamasını çeşitli şekillerde geliştirmektedir. Çalı̧̧mada, kentsel markalaşma süreci, kentsel markalaşma stratejileri bakımından ele alınacak, bu süreçte yerel yönetimlerin rolü ve önemi değerlendirilecektir.
\end{abstract}

Anahtar Kelimeler: Kentsel Markalaşma, Kentsel Strateji, Yerel Yönetimler, Kent İmajı

JEL Siniflandirması: N90, H79, L19

Abstract: The cities have now turned into attraction centers both commercially and politically with the rapid population growth and the increase in urbanization, This important role undertaken by cities has caused local governments to determine new strategies regarding urban policies. For this reason, municipalities have focused on creating new areas of responsibility in strategic city management in order to increase branding efforts in evaluating cities as centers of attraction and to redefine local economic values. Urban branding is a new approach to urban development of sustainable cities. City branding, a new aspect of urban communication, transforms the visual image of the city into a brand image and improves the marketing of the city image in various ways. In this study, the urban branding process will be discussed in terms of urban branding strategies, and the role and importance of local governments will be evaluated in this process.

Keywords: Urban Branding, Urban Strategy, Local Goverments, City Image

JEL Classification: N90, H79, L19

\section{Giriş}

Sanayileşme ile birlikte kentsel nüfusun hızla artması, kent yönetimi konusunda yapılan araştırmaların yönünü kentsel rekabet stratejilerine doğru çevirmiştir. Kentlerin ekonomik hayatta etkin olmasında ve yarışabilir konuma gelmesinde rekabet kavramı ön plana çıkmıştır. Ekonomik anlamda önemli yatırım merkezleri haline dönüşen kentler, sosyal ve kültürel anlamda da ön plana çıkmak için çeşitli stratejiler geliştirmeye başlamışlardır. Burada sadece turistlerin dikkatini çekmeyi, yatırımcıları şehre yönlendirmeyi amaç edinmemişler, aynı 
zamanda kentsel imajın ve itibarın arttırılması konusunda da çalışmalar yürütmüşlerdir. İnsanların tatil anlayışının değişmesi ve daha mobil hala gelmesi, turizm stratejilerinin de bu değişim üzerinden yorumlanmasına yol açmış, kentler de bu anlayış doğrultusunda yeni markalaşma yöntemleri geliştirmeye başlamışlardır.

Kentsel markalaşma, kentin diğer kentler arasında ön plana çıkmasında, tanınmasında ve imajını arttırmasında kullanılan önemli bir kavramdır. Kentsel markalaşma, farklı dinamiklere sahip olan özellikle kentsel cazibenin sağlanabilmesi etkin bir araç olarak değerlendirilmektedir. Kurumsal anlamda olduğu gibi kentsel anlamda da markalaşma, kentler için ayrı bir değerin yaratılması sürecini ifade etmektedir. Kentsel markalaşma, bir şehrin imajını, itibarını, güvenilirliğini, kapasitesini ve rekabetçi kimliğini yansıtmaktadır. $\mathrm{Bu}$ nedenle, diğer şehirlerle rekabet aşamasında öne çıkmayı ve seçkin bir konum elde etmeyi arzulayan şehirler, pazarlama ve markalaşma sürecine ilişkin çalışmalarını hızlandırmışlardır.

Kent ekonomisinin geliştirilmesinde ve kentsel kalkınmanın sağlanmasında önemli bir gelir kaynağı olan turizm, kentsel markalaşma stratejilerinin belirlenmesinde de dikkate alınmaktadır. Kentler, turizm gelirlerini artırmak için, turistlerin zihninde yer edebilecek, uygulanabilir, erişilebilir ve cazip kentsel markalaşma stratejileri geliştirmelidir. Bu tür stratejiler, kültürel mirasın ve yerel öğelerin ön plana çıkarılacağı unsurlar üzerinden şekillenmekte ve uygulamaya geçirilmektedir. Bu sebeple de kentsel markalaşma sürecinde yerel yönetimlerin görev sorumlulukları önem kazanmaktadır.

Kentsel markalaşma, yerel kalkınma dinamiklerinin oluşturulması aşamasında da önemli bir adım olmakta, oluşturulan stratejiler bölgenin kalkınmasına da yarar sağlamaktadır. $\mathrm{Bu}$ amaçla yerel kalkınmanın önemli bir aracı olarak markalaşma süreci, yerel yönetimlerin de dikkatle ve özenle üzerinde durması gereken bir konuyu oluşturmaktadır. Yerel yönetimlerin, kentsel öncelikler ve hizmetler konusunda çok daha etkin birim olmaları, stratejik kent yönetimi konusunda alınması gereken kararların ve uygulamaya konacak olan düzenlemelerin etkin bir şekilde hayata geçirilmesini kolaylaştırmaktadır.

$\mathrm{Bu}$ çalışmada öncelikle, kentsel markalaşma sürecinin inşasında ve kentsel markalaşma stratejilerinin oluşturulmasında yerel yönetimlerin rolünün ne olduğunun araştırılması amaçlanmaktadır. Bu doğrultuda da kentsel markalaşma kavramına ilişkin dinamikler ve unsurlar değerlendirilerek, kentsel markalaşma stratejilerinin temel hedefleri açıklanacak; son aşamada da yerel yönetimlerin bu süreçteki etkisi, görev ve sorumlulukları tartışılacaktır. 


\section{Kentsel Markalaşma}

Günümüzde mekân ve daha özel olarak kentsel markalaşma kavramı, özellikle kent yöneticileri arasında büyük bir ilgi görmüştür. Bu nedenle, mekân markalaşması alanında çalışanlar, kentlerin mevcut ve potansiyel hedef gruplara tanıtılmasını sağlamak ve zihinlerinde kentsel bir imge yaratmak amacıyla çeşitli ekonomik, politik veya sosyopsikolojik hedefler geliştirmektedirler (Kavaratzis ve Ashworth, 2005, s. 183). Rekabetin yalnızca uluslararası anlamda değil aynı zamanda yerel anlamda da şiddetlendiği günümüzde, ziyaretçileri çekmek amacıyla kent imajını iyileştirmek için yeni yöntemler ve stratejiler geliştirilmelidir. Bu bağlamda, Kotler ve arkadaşları (1993: 12-17), birçok kentin ve kasabanın "öldüğ̈̈̈nü veya kronik olarak depresyonda olduğunu", diğerlerinin "patlama ve çöküş özellikleri" yaşayabildiğini, küçük bir bölümünün de "kayırılmış azınlığın" sürekli ve güçlü büyümeye sahip olduğunu savunmaktadır.

Güçlü, pozitif ve dayanıklı bir marka oluşturmak ve yönetmek birçok zorluğa sahiptir. Hem uluslararası anlamda hem de kentsel anlamda, kentsel markalaşmanın ilk adımında kentsel imaj ve kentsel itibar hedeflerini belirlemek, uygulamak ve sürdürebilmek oldukça zor bir aşamadır. Bu sebeple de kentsel markalaşma sürecinde tanımların, hedeflerin, unsurların, prensiplerin ve kaynakların dikkatle belirlenmesi gerekir.

Kentsel markalaşma kavramı yeni bir kavramdır ve şehrin kendine özgü fiziksel özelliklerinin belirlendiği ve mekânın özünü oluşturan süreç olarak tanımlanmaktadır. Kentin yalnızca olumlu özelliklerinin sıralandığını dar bir anlatımdan ziyade, kente dair olan her şeyin anlamlandırıldığg bir anlatıma sahiptir. Kentsel markalaşma, yerel turizm organizasyonlarının, sanat ve kültür tesislerinin, müzelerin, tarihi koruma gruplarının mekan görüntülerinden yararlandığı ve inşa ettiği, tüketicileri çekmek ve belirli bir yerel bölgeye yatırım yapmak için turistik yerler üretmeye yardımcı olduğu bir farklılaşma ve çeşitlendirme sürecidir. Bu açıdan değerlendirildiğinde de kentsel markalaşmanın iki önemli unsuru bulunmaktadır (Rehan, 2014: 224-225):

- Bir şehrin konumu ya da mekânsal tasarımı, o yeri avantajlı ve çekici kılan önemli bir unsurdur.

- Kent markalaşması ya da kentsel pazarlama, belirli bir yerin/kentin avantajlı yapısını öne çıkarma sürecidir.

Ürün markalaşmasına benzer şekilde kentsel markalaşma da, kentsel imgeleri, kentsel biçimler, tarihi ve kültürel kimlik unsurlarıyla ilişkilendirmektedir. Şehrin imajını bölgenin geri kalanına veya genel olarak dünyaya iletmenin yeni ve yaratıcı yollarını geliştirmeyi 
amaçlamaktadır. Pek çok şehirde çeşitli amaçlarla, farklı yorumlamalarla ve çeşitli şekillerde, kentsel markalaşma stratejileri ve planları kullanılmıştır (Helmy, 2008: 9-11).

En basit tanımı ile kentsel markalaşma, pazarlama alanındaki geleneksel ürün yada hizmetler pazarlama stratejisinin kentlere aktarılması olarak karşımıza çıkmaktadır (Peker, 2006: 20). Burada kentsel markalaşma sürecindeki temel amaçlar, hedef kitle erişimi, yatırım artışı, ihracat artışı, turizmi geliştirmek, kenti eğitim-kültür gibi alanlar başta olmak üzere insanlara cazip hale getirmektir olarak sıralanabilir. Bu amaçların birçoğunun belirlenmesi ve hayata geçirilebilmesi kentin markalaşma unsurlarını da oluşturmaktadır.

"Yaşanılabilir kentlerin kalkınmalarının sürdürülebilirliğinin sağlanması ve sağlıklı yaşam alanlarının tesisi adına kentlilik bilincine sahip ve aidiyet hissiyatları gelişkin bireylerin, grupların ve toplumların sayılarının artırılarak, kentlileşme sürecinin sürdürülebilirliği sağlanmalıdır. Kentlerin büyüme, gelişme ve markalaşma süreçlerinde, kentlerde yaşamlarını sürdüren birey ve grupların kenti ve kent yapısını algılama biçimleri, kenti keşfetme motivasyonları, kentin doğal güzelliklerine dair geliştirdikleri farkındalık, kente dair oluşturdukları aidiyet hissiyatı, kenti ve değerlerini sahiplenme seviyeleri, kentin mevcut ve olası sorunlarına dair tutum ve davranışları, kent yönetimine ve kentsel kurumlara katılma edimleri, kent ile bütünleşme hissiyatları ve kentlilik bilinci olguları, kentlerin istikrarı ve yaşanılabilirliği adına büyük önem arz etmektedir. (Akova, 2020: 3357).

Kentsel markalaşma, kent imajının belirlenmesi ile başlayan bir süreçtir. Kent imajını, şehir markalaşma ilkelerinden inşa etme sürecini anlamak amacıyla, çeşitli yazarların tüm yaklaşımlarını tek bir fikirde bir araya getirmek gerekir. Kotler, Haider ve Rein (1993), yerin imajını "insanların bir yer hakkındaki inanç, fikir ve izlenimlerin toplamı" olarak tanımlamaktadırlar. İmajlar, yerle bağlantılı çok sayıda ilişkilendirmenin ve bilgi parçasının basitleştirilmesini temsil etmektedir. Bununla birlikte, bir yerdeki kişisel görüntüler, mekâna yönelik tutumları yansıtmayabilir. Şehrin aynı görüntüsü, her birinin ruh haline ve tutumuna bağlı olarak iki kişi için farklı anlamların oluşmasına neden olabilmektedir. Buna ek olarak, Blichfeldt (2005) bir yer imgesinin, “insanların bir dizi element birleşmesiyle kendi zihinlerinde ürettikleri bir şey" olduğunu savunmaktadır. Bu nedenle, insanların zihninde imge yaratma stratejisi, ancak şehrin tutarlı ve net bir imgesini yansıtma girişimi olabilir.

Başka bir açıdan Kavaratzis (2004), kentin imajını, "şehrin gönderdiği ve her bireyin zihninde ayrı ayrı oluşan farklı ve hatta çelişkili mesajların sonucu”" olarak tanımlamakta, böylece her bireyin kente karşı algısı farklılaşmaktadır. Bu nedenle, şehir sadece fiziksel ve nesnel bir alan değil, aynı zamanda bireylerin öznel algılarının oluşturduğu öznel bir alandır. Kentsel markalaşmanın amacı, şehre atfedilen çok çeşitli resim ve anlamları tek bir mesajda tanımlamak ve birleştirmek için bir temel sağlamaktır. 
Kente ve kentsel yaşama dair birbiriyle ilgili olan ağların ve bilgi yapısının zihinde oluşturduğu imgelerin bütünü olan kent imajı, bilişsel ve duygusal unsurların bir kombinasyonu olarak algılanmaktadır. Bahsi geçen bu özellikler, kişilerin kente ait özellikleri bilmesine ve tanımasına yardımcı olmaktadır. Kent imajının iyi olması, kentsel markalaşmanın da kolaylıkla tasarlanabilmesini, vatandaş memnuniyetinin sağlanabilmesini kolaylaştırmaktadır. Bu memnuniyet de, kentsel markalaşmanın başlangıç noktasında yerel yöneticilerin projelerinin yönünün belirlenmesinde etkili olmakta ve yerel ekonominin de bu doğrultuda ivme kazanmasına olanak sağlamaktadır.

Kent imajı, bu doğrultuda bireylerin kente dair tek tek algıladıkları düşünceleri ve duyguları ortak bir görüntüde birleştirebilmeyi hedeflemektedir. Şehrin görüntüsü, kentle ilgili tüm somut ve soyut olan unsurları harmanlar ve basitleştirir. Kent imajının belirlenmesi bu anlamda, kente dair özel vurguların ortaya konulması ve bunların ortaya çıkarılması ile mümkün olabilmektedir. Bu özel vurgular, şehrin kültürel yapısından kaynaklı doğrudan oluşabileceği gibi, medya ya da deneyimler yoluyla dolaylı olarak da sağlanabilmektedir. $\mathrm{Bu}$ nedenle, kent markası, yerel halkın ve ziyaretçilerin paylaştı̆̆ değerlere, inançlara ve fikirlere uygun bir imaj yansıtmak için bu kamusal imgelere odaklanmalıdır.

Markalaşma kavramından yola çıkarak içeriği oluşturulan kentsel markalaşmada, ürün markalaşma süreçlerinin kente aktarılması aşamalarından oluşmaktadır. Ancak ürünün markalaştırılmasından farklı olarak kent ölçeğinde kentte etkin olan farklı aktörler, sosyal yapı ve beraberinde kentin fiziksel mekanı da markalaşma stratejilerinde ön planda tutulmuştur (Eraydın, 2016: 835-836). Kentsel markalaşmaya ait çeşitli tanımlar ise aşağıda Tablo 1'de gösterilmiştir.

Tablo 1. Kentsel Markalaşma Tanımları

\begin{tabular}{|c|c|c|}
\hline \multicolumn{2}{|l|}{ Yazarlar } & Tanımlar \\
\hline $\begin{array}{l}\text { Nickerson and } \\
\text { (1999) }\end{array}$ & Moisey & $\begin{array}{l}\text { Kentsel markalaşma, insanlar ve yaşadıkları şehirlerinin imajı arasında bir } \\
\text { ilişki kurmaktadır. }\end{array}$ \\
\hline Hall (1999) & & $\begin{array}{l}\text { Kent markalaşmasının temel amacı "tutarlı ve odaklı bir iletişim stratejisi } \\
\text { sağlamaktır" }\end{array}$ \\
\hline Cai (2002) & & $\begin{array}{l}\text { Kent markası, destinasyon olarak şehir ile tanınırlık ve farklılaşma sağlamak } \\
\text { için pozitif bir imaj oluşturarak tutarlı bir marka faktörü kombinasyonu } \\
\text { seçmek demektir. Marka faktörleri arasında isimler, terimler, işaretler, } \\
\text { logolar, tasarım, sembol, slogan, ambalaj veya yukarıdakilerin kombinasyonu } \\
\text { yer alır; bunların arasında isim önceliktir. }\end{array}$ \\
\hline Rainisto (2003) & & Kentsel markalaşma, şehrin cazibesini artırma yöntemidir; esas olan şehrin \\
\hline
\end{tabular}




$\begin{array}{ll}\text { Kavaratzis (2004) } & \text { tanınırlığını sağlamaktır. } \\ & \text { Kent markalaşması, hem içe dönük yatırımı ve turizmi artırmak için rekabet } \\ & \text { avantajı elde etmenin hem de toplumsal kalkınmanın sağlanması, yerel } \\ & \text { kimliği ve vatandaşların kentleriyle özdeşleşmesinin sağlanması ve sosyal } \\ & \text { dışlanma ve huzursuzluktan kaçınmak için tüm sosyal güçlerin harekete } \\ & \text { geçirilmesi olarak anlaşılmaktadır. } \\ & \text { Kentsel markalaşma, şehrin niteliklerini yaratma ve zenginleştirme çabası } \\ & \text { olarak kabul edilmektedir. } \\ \text { Julier (2005) } & \text { Kentsel markalaşma, bazı şehirlerin imajlarını yeniden inşa etmek ve yeniden } \\ \text { Morgan and } & \text { Pritchard } \\ \text { (2007) } & \text { fanlamak için kullanıldığı için, aslında sadece mekân tanıtımından daha }\end{array}$

Kaynak: Casapi, I., Cela, A. (2017). Destination Branding: A Review of the City Branding Literature. Mediterranean Journal of Social Sciences. Vol 8 No 4. s. 137.

Tablo 1 değerlendirildiğinde kentsel markalaşma ile ilgili tanımların birçoğu kentsel tanıtım, imaj ve itibar kavramları üzerine kuruludur. Burada kentlerin cazibe noktası olarak değerlendirilmesi, ziyaretçileri çeken yönlerinin tanıtılması gibi unsurlar söz konusudur.

Belirli bir yerin kentsel stratejisinin şekillenmesi olarak kentsel markalaşma, imge, kent yaşamı ve şehir manzarası hakkındaki duygu ve algıların bir toplamını temsil etmektedir. Benzer şekilde, yeni kentsel iletişim alanı olarak kentsel markalaşma, şehir imajının pazarlanmasına ilişkin yöntemleri içermektedir. Ticari markalaşma ile şehir markalaşması arasındaki kavramsal fark, şehir markalaşma konumlarının bir dizi değer, anlam ve sosyal rolle ilişkili olmasıdır. Kentsel markalaşma, yerel halk, turistler, iş adamları ve yetkililer gibi geniş bir kitleye hitap ederken, ürün markaları yalnızca tek bir kitleyi veya tüketicileri tatmin etmek zorundadır. Şehir markasının temel özellikleri işlevsellik ve katma değerlerdir (Helmy, 2008: 10).

- Işslevsellik: Markalar gibi şehirler de işlevsel olmalıdır. Bir şehir, yaşama, çalışma, barınma, toplu taşıma, turizm, eğlence mekanları vb. için bir yer işlevi görmelidir. Birçok şehir, vatandaşları çekerek, yeni iş fırsatları sunarak, turizmi, yeni kültürleri ve eğlence tesislerini teşvik ederek, daha iyi konutlar sağlayarak daha iyi bir itibar ve statü oluşturmaya yönelik kalkınma stratejilerini, programlarını ve planlarını başarıyla gerçekleştirmiştir.

- Katma Değer: Şehir markaları sadece işlevsel faydalar sağlamakla kalmaz, aynı zamanda işlevsel olmayan katma değer de sağlamaktadır. Güçlü ve başarılı şehir markalarının sadakate çevrilen katma değerleri vardır. Katma değerlerin kaynakları, 
insanların deneyimlerine ve kent algısına göre değiş̧ebilir. Bunlar: Kentteki anlam ve inanç; şehrin estetiği ve görünümü, şehrin tarihi mirası, mimarisi ve yerel geleneğidir.

Kentsel markalaşma kavramının unsurlarına ilişkin bir başka değerlendirme de her iki yılda bir Ipsos'un on ülkede toplam 5.000 kişi ile yaptığı ankete dayanan, kentsel markalaşma indeksine aittir. Kentler, aşağıdaki hususların her biri üzerinden değerlendirilmekte ve sıralamalar bu hususlar doğrultusunda oluşturulmaktadır (placebrandobserver.com, 2020). ${ }^{1}$

- Uluslararası durum (Görünüş): Şehrin uluslararası statüsüne ve durumuna ve şehrin küresel olarak aşinalığına / tanınırlığına dayanmaktadır. Ayrıca şehrin bilim, kültür ve yönetişime küresel katkısını da ölçmektedir.

- Fiziksel cazibe (Yer): İnsanların, iklimin hoşluğu, çevrenin temizliği, bina ve parklarının çekiciliği açısından her şehrin fiziksel yönü hakkındaki algılarını keşfetmeyi amaçlamaktadır.

- Olanaklar (Ön Koşullar): İnsanların, tatmin edici, uygun fiyatlı konaklamanın olup olmadığı, okullar, hastaneler, ulaşım ve spor tesisleri gibi kamu hizmetlerinin standardı gibi şehrin temel niteliklerini nasıl algıladıklarını belirler.

- Sakinlerinin sıcaklı̆̆ (İnsanlar): Şehir sakinlerinin sıcak ve misafirperver olup olmayacağını, katılımcıların kendi dillerini ve kültürlerini paylaşan bir topluluk bulup bu topluluğa uyum sağlamalarının kolay olup olmayacağını ve kendilerini güvende hissedip hissetmeyeceklerini ortaya koymaktadır.

- Aktiviteler (Nabız): Boş zamanı dolduracak ilginç şeyler olup olmadığını ve keşfedilecek yeni şeyler açısından şehrin ne kadar heyecan verici olduğunu belirlemektedir.

- Eğitim ve iş nitelikleri (Potansiyel): Bir iş bulmanın ne kadar kolay olduğu, iş yapmak veya yükseköğrenim için iyi bir yer olup olmadığ́ gibi şehirdeki ekonomik ve eğitim fırsatlarını ölçmektedir.

\section{Kentsel Markalaşma Stratejileri}

İyi bir şehir imajı oluşturmak, anlamlı bir faaliyet ve yapı sentezidir. İmaj planlama stratejilerinin kullanımı, küresel ekonomide ayakta kalabilmek için şehirler için temel bir ihtiyaç haline gelmiştir. Başarılı bir markalaştırma süreci kentlerin, fiziksel yönlerinin gösterilmesinin ötesinde fayda sağlamakta, kentlerin çekiciliğini çok yönlü bir şekilde

\footnotetext{
${ }^{1}$ Anholt-Ipsos Şehir Markaları Endeksi için ankete katılan on ülkedeki kişilere göre Londra, Sidney, Paris, New York ve Roma ile dünyanın en iyi "Şehir Markası" dır.
} 
arttırmaktadır. Büyük ölçekli kentsel projeler, imzalı mimari, etkinlikler, medya vb. gibi çeşitli şehir geliştirme hedeflerine ve vizyonlarına dayalı olarak geliştirilebilecek farklı kentsel markalama stratejileri vardır. Kentsel markalaşma stratejileri, sadece şehir imajının tanıtımı ile sınırlı olmamakta, aynı zamanda kentlerin rolünü arttırarak kar elde etmek isteyen yatırımcıların, gayrimenkul sahiplerinin, mimarların, inşaat projeleri sahiplerinin de ilgi alanını oluşturmaktadır (Helmy, 2008: 12-16).

Kentsel markalaşma, insanların belirli bir yer hakkında bilmesi gereken temel şeylerdir. Bu yüzden de marka yaratma süreci, medya tarafından oluşturulan görüntülere, kentsel projelere ve şehir yaşamının, tarihi binaların, mimarinin ve şehrin genel biçiminin markalaşma stratejilerine bağlı olarak gelişmektedir. Kentsel markalaşma stratejilerine ilişkin süreci aşağıda Şekil 1 yardımı ile göstermek mümkündür.

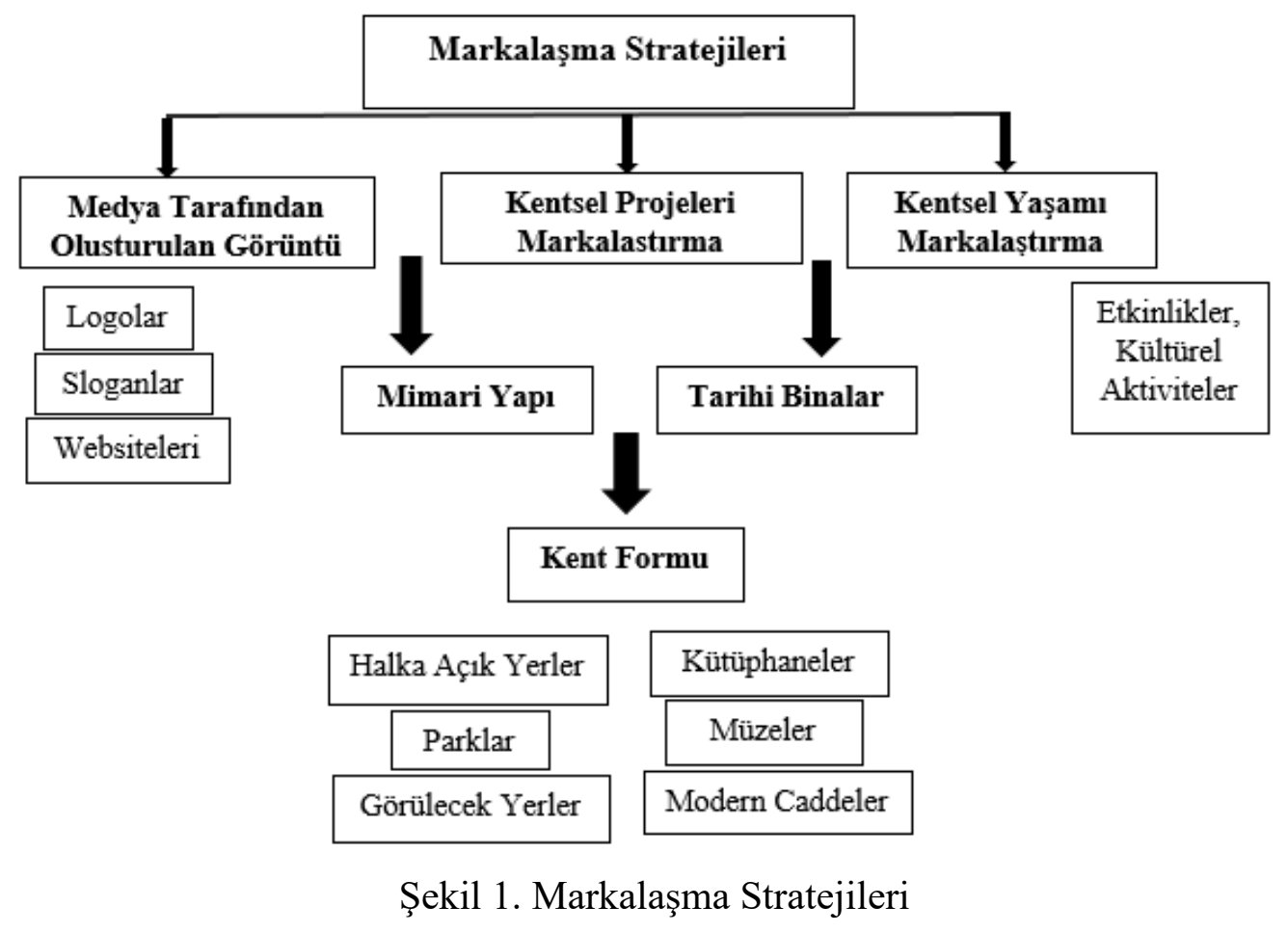

Kaynak: Reeman Mohammed Rehan (2014) Urban branding as an effective sustainability tool in urban development, HBRC Journal, 10:2, 222-230, DOI, s. 225.

Kentsel markalaşma stratejilerinin oluşturulmasında medyanın kullanılması, kentsel mimari özelliklerinin öne çıkarılması ve kentsel yaşamın pazarlanabilmesi için önemli bir araçtır. Burada yazılı ve görsel basın tarafından çekilecek tanıtıcı videolar, kentsel cazibe noktalarına vurgu yapacak sloganlar, kent yaşamını anlatan logo tasarımları ve kente ait görüntülerin, bilgilendirmelerin, yorumların yer alacağı bir website oluşturulması, kentsel 
markalaşma için önemli bir adımı oluşturmaktadır. Bunun yanı sıra kentsel markalaşma stratejileri oluşturulurken kent kültürünün anlatılması, yerel öğelere dikkat çekilmesi (örneğin "old town" cazibe noktaları gibi), kültürel etkinliklerin planlanması, adımları da önemli bir başlangıç noktası olmaktadır. Kentte yer alan müzeler, tarihi kütüphaneler, yeşil alanlar, kamusal alanlar, yürüyüş parkurları, bisiklet yolları, görülmesi gereken yerlerin listesi gibi unsurlar da kentsel markalaşma stratejisinin bir parçası olarak değerlendirilmektedir. Örneğin, New York için Central Park ve Times Meydanı, Lonra için London Eye, Hyde Park, Almanya için Alpler, İstanbul için Kız Kulesi, Kastamonu için Safranbolu, İzmir için Saat Kulesi gibi kent imajları, kentsel markalaşmanın önemli göstergelerindendir.

Kent imajını oluşturmak veya iyileştirmek için kentsel markalaşma stratejileri ve planları için ana hedefleri şu şekilde sıralamak mümkündür (Mohammadi ve Marofi, 2018: 154-156):

- Bölgesel ve uluslararası rekabet avantajları elde etmek,

- Ekonomik rolünü iyileştirmek için bir şehrin itibarını ve kurumsal kimliğini güçlendirmek

- Daha iyi bir kamusal alan ve farklı bir yer duygusu sağlayarak sakinler için kentsel yaşam kalitesini iyileştirmek

- Kültürel çeşitliliği birçok şehrin yaşamının önemli bir özelliği olarak korumak ve eski haline getirmek

- Şehirlerde okunabilirliği ve erişilebilirliği iyileştirmek

Buna ek olarak başarılı bir şehir markalaşma stratejisi oluşturmak için şu aşamalar da takip edilmelidir (www.bloom-consulting.com, 2020):

- Merkezi fikre dayalı bir marka stratejisi: İlk olarak, bir kent markasının gerçekte ne olduğunu ve amacını anlamak çok önemlidir. $\mathrm{Bu}$, insanların bir yer hakkındaki algılarını gerçeklikle uyumlu hale getirmek için bir strateji geliştirmekle ilgilidir. Herhangi bir kentsel markalaşma stratejisinin temel amacı, bir ülke, bölge veya şehir hakkındaki yanlış düşünceleri ortadan kaldırmak ve onu benzersiz, özel ve ilgi çekici kılan şeylerin uluslararası farkındalığını artırmaktır. Başarılı kent markasının temel taşı, tutarlı ve uzun vadeli bir stratejinin geliştirilmesidir.

- Doğru organizasyon yapısı: Kentsel markalaşma stratejisinin en büyük zorluklarından biri, stratejinin herhangi bir hükümet değişikliğine uyarlanabilir şekilde uygulanmasını ve yönetilmesini sağlamaktır. Marka yönetim ekibinin, mevcut ve gelecekteki politik koşullara rağmen marka stratejisini yürütmek, yönetmek ve sürdürmek için kendi kaynakları ve gerçekçi bir bütçesi olmalıdır. İdeal yönetim yapısı, işlerin 
gerçekleşmesini sağlayan tutkulu, deneyimli, yetenekli ve dirençli bir ekiple donatılmış bir yapıdır.

- Temel performans göstergelerini ve ölçüm süreçlerini netleştirme: Marka ekibi tarafından faaliyetlerin sürekli izlenmesi ve sonuçların ölçülmesi, kentsel markalaşmanın başarısının anahtarıdır. Bu oluşum, verilen politikaya uyulmaması veya projelerin yetersiz teslim edilmesi durumunda yönetimin müdahale etmesine izin verir. Bunu yapmanın en iyi yolu, her bir marka eylemi, etkinliği ve projesinin yanı sıra genel stratejiye somut temel performans göstergeleri atamaktır. Bununla birlikte, ekonomik ve sosyal göstergeler, bir markanın stratejisinin gerçek etkisini değerlendirmeyi mümkün kılacaktır.

- Dijital Kimlik Yönetimi: Onlarca yıl önce yapılan ilk girişimlerden bu yana, kentsel markalaşma uygulamaları zaman içinde değişmiştir. Dijital dünyada olanların gerçek dünya paydaşlarının algıları ve eylemleri üzerinde muazzam bir etkisi vardır. Artık kentler, dijital çağda başarılı olmak için stratejilerini geliştirmek için yeni yollarla çalışmalıdır. Dijital düşünmeli ve hareket etmelidirler.

Kentsel markalaşma stratejilerinin oluşturulması süreci dikkatle planlanması gereken adımlardan oluşmalı, bütüncül ve çok aktörlü bir yapı içerisinde düşünülmelidir. Kentsel markalaşma stratejilerinin uzun vadeli oluşturulmasında ilk aşamada kente ait tüm verilerin analizinin yapılması gerekmektedir. Burada kullanılacak olan SWOT analizi ile kentin konumu, coğrafi koşulları, üretim imkânları, sosyo-kültürel değerleri saptanarak hangi faktör üzerinde durulacağı kararlaştırılmalıdır. Kentin sahip olduğu firsatlar, avantajlar, dezavantajlar, güçlü yönler belirlenmeli, olumsuz açılar olumluya çevrilmek amacıyla yeniden düzenlenmelidir. Kentin dinamiklerinin ve çekici yönlerinin ön plana çıkarılabilmesi için kent içerisinde yaşayan tüm aktörler sürece dâhil edilmeli, kent imajının oluşturulmasında onların görüş ve önerileri de değerlendirilmelidir. Bunun için atılması gereken adımlar ise Tablo 2'de gösterilmiştir. 
Tablo 2. Kentsel Sembol Markalaşmasının Geliştirilmesi İçin Gerekli Stratejiler Ve Çözümler

\begin{tabular}{|c|c|}
\hline Analiz Konuları & Kentsel Markalaşma Stratejisi \\
\hline $\begin{array}{l}\text { Marka } \\
\text { stratejisi }\end{array}$ & $\begin{array}{l}\text { Marka farklılaşmasının kentsel özelliklerini diğer kentsel turizm destinasyonlarına } \\
\text { göre görselleştirmede etkin hatırlama gücünün artırılması }\end{array}$ \\
\hline $\begin{array}{l}\text { Markaya bağlılık } \\
\text { stratejisi }\end{array}$ & $\begin{array}{l}\text { Markayı yeniden değerlendirmek, rakiplerden daha fazla avantaj elde etmek, } \\
\text { geliştirmeyi güncellemek, başkalarına tavsiye etmek }\end{array}$ \\
\hline $\begin{array}{l}\text { Algilama kalitesini } \\
\text { artırma stratejisi }\end{array}$ & $\begin{array}{l}\text { Turistlere yönelik hizmet sunumunda çok yönlü tutum, hizmet deneyimi, anlayış } \\
\text { bakış açıları ve hizmet kalitesi, yüksek kaliteli altyapılar, temiz çevre, uygun hizmet } \\
\text { fiyatı, reklam ve uygun bilgilendirme gibi unsurlarla artırılmalıdır. }\end{array}$ \\
\hline Marka imajı stratejisi & $\begin{array}{l}\text { Kültürel cazibe merkezleri ve boş zaman için uygun yerlerde yerel kentsel imaj1 } \\
\text { geliştirmek }\end{array}$ \\
\hline yönetim & $\begin{array}{l}\text { Özellikle kentsel sembollere uygun pazarlama ve reklam amaçlarını entegre etmek } \\
\text { için şehir yöneticileri ve turizm organizasyonu yöneticilerinin ortak politika yapımını } \\
\text { birleştirmek }\end{array}$ \\
\hline $\begin{array}{ll}\text { Finansal ve } & \\
\text { ekonomik strateji }\end{array}$ & $\begin{array}{l}\text { Finansal ve ekonomik kaynaklar arasında birbirleriyle uyum sağlayan doğal unsurlar } \\
\text { ve turistik cazibe merkezleri arasında ilişki kurmak ve başarılı bir markalaşmaya yol } \\
\text { açmak için konferanslar düzenlemek }\end{array}$ \\
\hline $\begin{array}{l}\text { Uluslararas1 } \\
\text { pazarlama stratejisi }\end{array}$ & $\begin{array}{l}\text { Kent sembolünün uygun ve en iyi şekilde markalaşmasını sağlamak için, küresel } \\
\text { olarak mevcut deneyimler mevcut gerçeklere göre yerelleştirilmeli ve kent itibarına } \\
\text { uygun bir görselleştirme ulusal ve uluslararası düzeyde yapılmalıdır. }\end{array}$ \\
\hline Yatırım stratejileri & $\begin{array}{l}\text { Kentin artan kültürel, tarihi, rekreasyonel ve ekonomik kabiliyetleri doğrultusunda } \\
\text { yerli ve yabancı yatırımcıları çekmeye uygun stratejiler benimsenmelidir. }\end{array}$ \\
\hline
\end{tabular}

Kaynak: Zarandi, H. ve arkadaşlarl (2016). Effective Factors on Urban Brand and Their Prioritization from Perspective of International Tourists (Case Study: Tehran's Milad Tower).

The Scientific-Research Quarterly Journal of Urban Economics and Management. Vol. 4, No.14. Pages:c117-136.

\section{Kentsel Markalaşma Sürecinde Yerel Yönetimlerin Önemi}

Kent markalaşması, hem içe dönük yatırımı ve turizmi artırmak için rekabet avantajı elde etmenin hem de toplumsal kalkınmanın sağlanması, yerel kimliğin güçlendirilmesi ve vatandaşların kentleriyle özdeşleşmesinin ve sosyal yaşamdan kaçınmak için tüm sosyal güçlerin harekete geçirilmesinin bir aracı olarak anlaşılmaktadır.

Kentsel markalaşma sürecinin en karmaşık ve sorunlu aşamasını oluşturan kent imajının belirlenmesi aşaması, farklı araçlar ile analiz yöntemlerininin kullanılmasını gerekli kılmaktadır. Bu sebeple de analiz sürecinin organizasyonundan, çıktıların oluşturulmasına kadar olan süreçte karar alıcılar ve uygulayıcıların rolü artmaktadır. Burada özellikle karar alıcıların kentin imajının belirlenmesinde reklam ve tanıtım faaliyetlerini organize etmesi, 
tasarım aşamalarını bu konuda teknik bilgiye sahip uzman kadrolar ile başlatması gerekmektedir (Garcia, 2011: 97).

Kent imajının oluşturulması, bütünsel bir yaklaşım içerisinde ele alınmalıdır. Çünkü burada kentte yaşayan vatandaşların kente yükledikleri anlamların belirlenebilmesi, kentin ruhuna özgü imgelerin seçilebilmesi ve bunun herkesçe kabullenmesi gerekmektedir. Örneğin, bir kente ait bir çeşmenin, kent ile özdeşleşmesi bir kentin hafizasını oluşturması, kentte yaşayan vatandaşların anılarını bakılarak anlamlandırılabilir ve kentsel imaj haline dönüştürülebilir. Bu anlamda da değerlendirildiğin yerel yönetimler bu konuya ilişkin güncel gelişmeleri takip ederek, dijitalleşmenin sağladığı avantajlardan yararlanarak süreç tasarım sürecine geçiş yapmalıdır (Villar, 2018: 32-33).

Yerel yönetimler genel manada vatandaş katılımının sağlanması aşamasında bazı görev ve sorumluluklara sahiptir. Bu unsurları kentsel markalaşmanın oluşturulması için de uyarlamak mümkündür. $\mathrm{Bu}$ süreçte yerel yönetimlerin kentsel markalaşma stratejilerinin oluşturulmasında aşağıda sıralanan sorumlulukları yerine getirmeleri önem arz etmektedir (Karyakov ve Sisk, 2003, s.30-31, Aktaran, Özden, 2020: 80-85):

- Toplantı organize etme: Yerel yönetimler kentsel markalaşma stratejilerinin belirlenebilmesi, kentin dinamiklerinin ortaya çıkarılabilmesi için sürece katkı sağlayacak tüm aktörlerin fikirlerini ifade edebileceği müzakere toplantıları düzenlemelidir. $\mathrm{Bu}$ toplantıların kapsayıcılığının yüksek olması kent imajının belirlenebilmesinde, kent tanıtımının yapılmasında önemli bir adım olacaktır.

- Arabulucu/uzlaştırıcı olma: Yerel yönetimler, stratejik kent yönetiminin planlanma sürecinde merkezi yönetim ve kentsel aktörler arasında köprü görevi görmelidir. Ortaya çıkan önerileri doğru aktarabilmeli, merkezi yönetim kaynaklarını doğru yönlendirebilmelidir.

- Kararların etkin ve hızlı alınmasını sağlama: Kentsel markalaşmaya ilişkin adımların doğru ve sağlıklı ilerleyebilmesi, somutlaştırılabilmesi için yerel yönetimler, kararların etkin ve hızlı alınmasını sağlamalıdır.

- Kaynak sağlama: Kentsel markalaşma, pazarlama fonksiyonundan yararlandığı için kent tanıtımının doğru şekilde yapılabilmesi, medyanın kullanılabilmesi, tasarım süreçlerinin oluşturulabilmesi için belirli bir bütçeye ve ekibi ihtiyaç duymaktadır. $\mathrm{Bu}$ sebeple de yerel yönetimler bu konuda kaynak sağlama ve fon oluşturma konusunda yardımcı olmalı, işbirlikleri sağlamalıdır. 
- Doğru bilgi aktarma: Markalaşma süreci, bilginin doğru şekilde işlenmesini, yaygınlaştırılması gerekli kıldığından, yerel yönetimler bu süreçte bilgiye erişimi kolaylaştırmalı, süreç konusunda şeffaf yöntemler izlemelidir. Böyle olunca ortaklaşa hareket alanları çoğalabilir, kentsel markalaşma stratejilerini net bir şekilde belirlenebilir.

- Teknik yardım sağlama (uzman personel de dâhil olmak üzere): Kentsel markalaşma süreci dikkatle tasarlanması gereken bir süreç olduğundan, bu konuda teknik personellere ihtiyaç vardır. Örneğin, halkla ilişkiler elemanı, yazılım elemanı, logo tasarım elemanı, iletişim uzmanı, pazarlama uzmanı, strateji uzmanı gibi.

- Kapasite geliştiren olma (özellikle markalaşma ĕgitimlerinin verilmesi aşamasında): Yerel yönetimler, kentsel markalaşma konusunda teknik detayların doğru şekilde anlatılabilmesi için çalıştaylar, seminerler, workshoplar, festivaller, kampanyalar gibi konularda sürece katkı sağlamalıdır.

Yerel yönetimler, bir dizi yerel hizmet sunar, sakinlerin yaşamını ve özgürlüğünü korur, demokratik katılım ve sivil diyalog için alan yaratır, piyasa öncülüğünde ve çevresel olarak sürdürülebilir yerel kalkınmayı destekler. Kentsel markalaşma, yerel kalkınmayı sürdürmek için şehir geliştirme politikası için ilkeleri sağlar. Yerel yönetimler, hedef bölgesel kalkınmada kaçınılmaz bir rol oynamaktadır. Yerel ekonomiyi desteklemek ve destinasyonu yaşamak, çalışmak ve iş yapmak için çekici bir yer haline getirmek için arazi kullanım planlaması, altyapı, ekonomik düzenlemeler ve diğer tesisleri sağlarlar. Bu başarıda yerel yönetimler kilit rol oynamaktadır. Yerel yönetimler, topluluklarının yararını en üst düzeye çıkarmak için yetki, altyap1, politika ve planlama prosedürleri sağlayabilir. Bir topluluğun gelişiminde daha büyük bir rol üstlenirler, insanlar ve hükümet arasındaki bağlantıları sağlarlar, topluluğun sorunlarını ve endişelerini ele alırlar, politikaları uygularlar ve topluluklarını etkilerler. Yerel yönetimler aynı zamanda, yararlı bir sonuç yaratmak için hükümet çerçevesini her bir topluluğa yönlendirmede aracılardır.

Kentsel markalaşma sürecinde rekabet edilebilir kentler yaratma düşüncesi yerel unsurların korunması, tanıtılması ve sürdürülebilmesi aşamasında önemli hale geldiğinden, yerel yönetimler bu süreçte kilit aktör olarak yer almaktadır. Dolayısıyla yerel yönetimlerin, merkezi yönetimlere nazaran daha etkin olması beklenmektedir. Yerel yönetimlerin merkezi politikaların uygulanma aşamasında tamamlayıcı bir rol üstlenmesi bölgesel dinamiklere uygun stratejilerin geliştirilmesini de kolaylaştırmaktadır. Etkin bir yerel yönetim sistemi, kentsel dinamiklerin belirlenmesinde, kentsel dokunun korunmasında, kent stratejilerinin 
belirlenmesinde ve sürdürülebilir kentsel politikaların oluşturulmasında önemli bir rol oynamaktadır. Bu sebeple de kentsel markalaşma stratejilerinin belirlenmesinde yerel yönetimlerin rolü, o ülkedeki merkeziyetçilik anlayışına ve görev ve yetki paylaşımına bağlı olarak değişmektedir. Merkeziyetçiliğin yoğun olduğu yapılarda, kentsel politikalar da merkezi yönetim tarafından belirlendiğinden bölgeye yapılacak yatırımlar ya da alınacak kararlar merkezi politikalar ile belirlenmekte; stratejik kent yönetimi hususunda yerel yönetimler geri planda kalmaktadır.

Türkiye'de şehirlerin markalaşma politikaları genellikle belediyeler ve valilikler tarafından belirlenmektedir. $\mathrm{Bu}$ politikaların belirlenmesi ve uygulanması noktasında kentsel yerel yönetim olan belediye ve yerel kamu yönetimi olan valilik kurumlarının ortaklaşa bir yaklaşımla hareket etmesi sayesinde etkin sonuçlar alınması beklenmektedir. Her ne kadar şehrin markasının unsurlarının tanımlanması zor olsa da, belediyelerin politikaları ve ilişkilerinin, yerel ve dış topluluklar ve karar vericilerle ilişkileri üzerinde derin etkileri bulunmaktadır. Tam kapasitede şehir markasına ulaşmak için yerel iş dünyası ve kurumlar, yerel ve ulusal medya, merkezi kamu yönetimi (valilik), komşu ülkeler ve şehirler ve diğer uluslararası ve çok uluslu organizasyonlar ile iyi ilişkiler kurmak esastır (Zeren, 2011: 31-35).

\section{Sonuç}

Küreselleşen dünyada yerel yönetimler artık, sadece klasik belediyecilik hizmetlerinin gerçekleştirilmesinden sorumlu değil, aynı zamanda kent hafızasının korunmasından, yerel halkın memnuniyet düzeyinden ve kentin diğer kentler arasında ön plana çıkması faaliyetlerinde de sorumludur. Yönetim anlayışının yönetişim anlayışına evrilmesi ile birlikte başlayan değişim süreci, beraberinde etkinlik, şeffaflık, kaynakların doğru kullanımı, çok aktörlülük, ulaşılabilirlik gibi kavramların hem ulusal hem de yerel düzeyde dikkate alınmasını gerekli kılmıştır. Bu anlayış doğrultusunda başlayan değişim, kentlerin de rolünü genişletmiş, belediyeciliğin sadece kentsel hizmet sağlama olmadığını ortaya çıkarmıştır.

Kentlerin cazibe merkezi haline dönüşmesi, kentler arasında rekabet süreçlerinin hızlanmasına, çeşitli stratejik adımların atılma zorunluluğunun başlamasına sebep olmuştur. Kentte yaşayan yerel halkın, yerel öğelerin korunması konusunda daha istekli olması, yerel yönetimlerin “yerel öğeleri” ön plana çıkararak, kent imajlarını yaratmasına kaynaklık etmiştir. Kenti oluşturan dinamiklerin, unsurların ve yapı taşlarının ziyaretçileri etkileyerek tanıtımının sağlanması, markalaşma stratejilerinin kentsel alanlara da yansımasına neden olmuştur. 
İnternet kullanım oranlarının artması, sosyal medya ağlarının genişlemesi ile birlikte tanıtım kampanyalarının yaygınlık kazanması, insanların daha mobil hale gelmesine neden olmuş; kentten beklenen özellikler değişime uğramıştır. Kentten beklenenler artık, yaşam koşullarının iyi olması, yeşil alanlarının yoğunluğu, sosyal ortamların fazlalığı, kültürel etkinlikler, akıllı şehirler, tarihi alanlar gibi görseller ve imajlar üzerinde yoğunlaşmıştır. Beklentilerin daha çok yaşam kalitesi üzerinde yoğunlaşması, yerel yönetimlerinin de görev ve sorumluluk alanlarını genişletmiş, bu süreçte etkin bir konuma gelmelerine neden olmuştur.

Kentsel markalaşma stratejilerinin oluşturulması, yoğun mesai gerektiren bir tasarım sürecinin. Bu tasarım sürecinde yerel yönetimler hem izin ve onay konusunda etkin olmakta, hem de sürecin hızlandırılması, kaynakların etkin kullanılması ve çok aktörlü bir ortamın oluşturulması için önemli görevler üstlenmektedir. Başarılı bir kentsel markalaşma süreci yerel yönetimlerin kent imajı konusunda vizyon sahibi olmasına, merkezi yönetim ile ilişkilerine, gelişmeleri takip etmesine, teknik ekibe ve yerel vatandaşları sürece dahil edip etmemesine göre değişmektedir. Bu unsurlara öncelik verilmesi, daha fazla turist çekmek için şehir yöneticilerinin ilgisini çekecek ve kentsel markaların sürdürülebilirliğini sağlayacaktır. 


\section{KAYNAKÇA}

Akova, S . (2020). Kent Kimliği Göstergeleri Üzerinden Kentlilik Bilincine Dair Bir Okuma: Yalova Kenti Örneklemi, OPUS Uluslararası Toplum Araştırmaları Dergisi , Cilt 16 - 29 Ekim Özel Sayısı, 33443386 . DOI: $10.26466 /$ opus.770453

Bastaman, A. (2018). Bandung City Branding: Explorıng The Role Of Local Community Involvement To Gain City Competitive Value. Journal of Entrepreneurship, Business and Economics. 6(1), 144-165.

Blıchfeldt, B. S. (2005). “Unmanageable Place Brands?” Journal Of Place Branding And Public Diplomacy, 1 (4): 388-401.

Cai, xxx. (2002). Cooperative branding for rural destinations. Annals of Tourism Research, Vol. 29, No. 3, pp. 720-742.

Casapi, I., Cela, A. (2017). Destination Branding: A Review of the City Branding Literature. Mediterranean Journal of Social Sciences. Vol 8 No 4. s. 137.

Eraydın, Z. (2016). Kentsel Markalaşma Stratejilerinin Kent Belleği ve Kent İmgesi Üzerine Etkileri: Ankara Örneği. İçinde. İdealkent Bellek ve Kentsel Koruma II, (Ed.) Altunoğlu, M. ve arkadaşları. Kent Araştırmaları Enstitüsü. ANKARA s. 830-856.

Hall, D. (1999). Destination Branding, Niche Marketing and National Image Projection in Central and Eastern Europe, Journal of Vacation Marketing, No. 5, pp. 227-237.

Helmy, M. (2008). Urban Branding Strategies and The Emerging Arab Cityscape: The Image of the Gulf City, Stadtebau Institut Universitat Stuttgard. s. 9-18.

Hernandez-Garcia J, Lopez C. (2011). Is There a Role for Informal Settlements in Branding Cities? Journal of Place Management and Development 4(1): 93-109.

Julier, G. (2005). Urban Design spaces and the Production of Aesthetic Consent, Urban Studies, Vol.42, pp.5-6, 689-888.

Karyakov, I. ve Sisk, T.D. (2003). Participatory Democracy. Karyakov, I. ve Sisk, T. D. (Ed.). Democracy at the local level: a guide for the South Caucasus içinde. International Institute for Democracy and Electoral Assistance, s. 25-35.

Kavaratzis, M. (2004). From city marketing to city branding: Towards a theoretical framework for developing city brands, Journal of Place Branding, Vol.1, No.1, pp.58 - 73.

Kavaratzis, M., Ashworth, G. J. (2005). City branding: An effective assertion of identity or a transitory marketing trick? Tijdschrift voor Economische en Sociale Geografie 96(5):506-514

Kotler, Philip, Rein I. and Haider, H.D. (1993), Marketing Places: Attracting Investment, Industry and Tourism to Cities, Regions and Nations, Free Press, New York.

Mohammadi, A., Marofi, S. (2018). Evaluation Of Urban Branding Strategies İn Iranian Cities. International Journal of Human Capital in Urban Management, 3(2): 153-166.

Morgan, N. and Pritchard, A., (2007). De-centring tourisms intellectual universe, or traversing the dialogue between change and transition. In Ateljevic, I., Pritchard, A, and Morgan, N. (eds.) The Critical Turn in Tourism Studies: Innovative Research Methodologies, pp. 11-28. Amsterdam: Elsevier.

Nickerson, N. amd Moisey, R. (1999). Branding a State from Features to Positioning: Making it Simple? Journal of Vacation Marketing, Vol. 5, No. 3, pp.217-226.

Özden, M. (2020). Katılımcı Demokrasi ve Yerel Yönetimlerde Katılım: Trakya Örneği. Marmara Üniversitesi Sosyal Bilimler Enstitüsü Yerel Yönetimler A.B.D Doktora Tezi. İSTANBUL.

Peker, A. Esra (2006). Kentin Markalaşma Sürecinde Çağdaş Sanat Müzelerinin Rolü: Kent

Markalaşması Ve Küresel Landmark, Yüksek Lisans Tezi, İstanbul: İstanbul Teknik

Üniversitesi Fen Bilimleri Enstitüsü.

Rainisto, S. (2003). Success factors of place marketing: A study of place marketing practices in Northern Europe and the United States, PhD thesis, Helsinki University of Technology, Institute of Strategy and International Business.

Rehan, M. (2014) Urban Branding As An Effective Sustainability Tool İn Urban Development, HBRC Journal, 10:2, s. 222-230.

The Basics of a Successful Country or City Brand Strategy, (2020). https://www.bloomconsulting.com/journal/the-basics-of-a-successful-country-or-city-brand-strategy/. Erişim Tarihi: 18.01.2021.

Villar, F. (2018). City Branding And The Theory Of Social Representation. Bitacora Urbano Territorial 28(1):31-36.

Zarandi, H. ve arkadaşları (2016). Effective Factors on Urban Brand and Their Prioritization from Perspective of International Tourists (Case Study: Tehran's Milad Tower). The Scientific-Research Quarterly Journal of Urban Economics and Management. Vol. 4, No.14. Pages:c117-136. 
Zeren, H. (2011). Marka Kent Oluşturma Bağlamında Stratejik Kent Yönetimi: Karaman Kenti İçin Bir Model Önerisi. İnönü Üniversitesi Sosyal Bilimler Enstitüsü Kamu Yönetimi Ana Bilim Dalı Doktora Tezi. MALATYA. 